\title{
Doing more harm than good? Community based natural resource management and the neglect of local institutions in policy development
}

Article

Accepted Version

Kamoto, J., Clarkson, G., Dorward, P. and Shepherd, D. (2013) Doing more harm than good? Community based natural resource management and the neglect of local institutions in policy development. Land Use Policy, 35. pp. 293-301. ISSN 0264-8377 doi:

https://doi.org/10.1016/j.landusepol.2013.06.002 Available at https://centaur.reading.ac.uk/33328/

It is advisable to refer to the publisher's version if you intend to cite from the work. See Guidance on citing.

To link to this article DOI: http://dx.doi.org/10.1016/j.landusepol.2013.06.002

Publisher: Elsevier

All outputs in CentAUR are protected by Intellectual Property Rights law, including copyright law. Copyright and IPR is retained by the creators or other copyright holders. Terms and conditions for use of this material are defined in the End User Agreement. 


\section{www.reading.ac.uk/centaur}

\section{CentAUR}

Central Archive at the University of Reading

Reading's research outputs online 
Doing more harm than good? Community based natural resource management and the neglect of local institutions in policy development

\section{Abstract}

Approaches to natural resource management emphasise the importance of involving local people and institutions in order to build capacity, limit costs, and achieve environmental sustainability. Governments worldwide, often encouraged by international donors, have formulated devolution policies and legal instruments that provide an enabling environment for devolved natural resource management. However, implementation of these policies reveals serious challenges. This article explores the effects of limited involvement of local people and institutions in policy development and implementation. An in-depth study of the Forest Policy of Malawi and Village Forest Areas in the Lilongwe district provides an example of externally driven policy development which seeks to promote local management of natural resources. The article argues that policy which has weak ownership by national government and does not adequately consider the complexity of local institutions, together with the effects of previous initiatives on them, can create a cumulative legacy through which destructive resource use practices and social conflict may be reinforced. In short, poorly developed and implemented community based natural resource management policies can do considerably more harm than good. Approaches are needed that enable the policy development process to embed an in-depth understanding of local institutions whilst incorporating flexibility to account for their location-specific nature. This demands further research on policy design to enable rigorous identification of positive and negative institutions and ex-ante exploration of the likely effects of different policy interventions.

\section{Keywords}

Local institutions, social capital, elite capture, policy development, community based management, decentralisation. 


\section{Introduction}

Decentralised forms of natural resource management are seen mechanisms for sustainability as local communities are empowered to make decisions over natural resource use (Ribot, 2002; Tacconi et al., 2006). The success of these approaches, however, depends upon the careful development of policy.

Governments have formulated devolution policies and legal instruments for natural resources, providing an enabling environment for devolved management. However, implementation of these policies has revealed a number of challenges, with many policies "reflecting rhetoric more than substance" (Shackleton et al., 2002, pp. 1) while communities yield limited benefits and the state promotes its own conservation or revenue interests ahead of rural livelihoods (ibid). In the case of the forestry sector, governments and local actors involved in devolved Community Based Forest Management (CBFM) programmes face problems which include burdensome regulatory frameworks, limited transfer of authority and overly specified powers to local organisations, choice of unrepresentative local organisations to receive the powers, lack of transparency and accountability of organisations charged with forest management, usurpation of power by local elites, and the undermining of local institutions (Ribot, 2002; Shackleton et al., 2002; Hobley, 2005; Zulu, 2009).

Institutions are defined by Pelling et al. (2008, p. 868) as "the constraints that shape social behaviour...that provide common ground for the negotiation and performance of power and influence in relationships between individuals and groups". These constraints are commonly divided between 'informal' and formal' institutions. Pelling et al. (ibid, p. 869) describe informal institutions as "embedded and tacit [including] intangibles such as cultural norms, values and accepted ways of doing things" and formal institutions as "visible and subject to rational control and management through public institutional frameworks". The 'local institutions' considered in this paper include both formal and informal institutions but predominantly the latter. Whilst by no means perfect, with the potential for abuse by power holders and disadvantages for those with the least power (Toulmin, 2008), local institutions are able to provide knowledge and capacity to help implement policy initiatives. They have the potential to "mediate external interventions into local contexts, and articulate between local and extra-local social and political processes... [shaping] the acquisition and distribution of these interventions in fundamental ways, thereby affecting the degree of success of such interventions" (Agrawal and Perrin, 2008, pp. 2). Understanding the role that local institutions play within a community is important when considering natural resource management initiatives 
because of this mediating role. Furthermore, local institutions can help to shape social capital ${ }^{1}$ (ibid), which in turn can improve household welfare through information sharing, collaborative working (reduction of opportunism) and improved collective decision making (Grootaert and Narayan, 2004). While the value of local institutions is recognised in devolution policies for natural resource management, incorporating them into policy development is not straightforward. Furthermore, for local institutions to act as robust mechanisms for natural resource management they may require strengthening, which necessitates a long-term context driven approach (ibid). This approach may be at odds with existing norms in policy development.

\subsection{Aims}

The aims of this paper are to: Explore the effects of limited involvement of local people and institutions in policy development and implementation; understand the role that local institutions play in mediating policy; and, consider the consequences of omitting local institutions from policy processes. Considering the roles of local institutions and how policy can best take account of them is important at a time when governments and non-governmental organisations (NGOs) are seeking to improve natural resource management and develop mechanisms for sustainability. They are also looking for local communities to be more involved in shaping their own futures.

\section{Methods}

The development and implementation of the Malawian Forest Policy (1996) present an appropriate opportunity to explore the relationship between local institutions and natural resource management policy development because it is an example of a donor driven process that seeks to implement international thinking on sustainable development and community managed natural resource management. The study was carried out in Lilongwe District in the Central Region of Malawi between August 2006 and May 2007. Lilongwe district was selected due to the increased pressure on woodlands because of the high population density and the exposure of local communities to a range of stakeholders through projects connected to Forest Policy implementation (e.g. Lilongwe Forest Project, Community Partnership for Sustainable Resource Management, Malawi Social Action Fund, EU Village Investment Forestry and Total Land Care). The study was interdisciplinary, combining scientific and social scientific investigation, which incorporated qualitative and quantitative methods of data collection. This involved an assessment of 33 Village Forest Areas (VFAs), including key informant interviews and forest resource assessments. These assessments

\footnotetext{
${ }^{1}$ Putnam (1993, p. 167) defines social capital as "features of organisation, such as trust, norms and networks that can improve the efficiency of society by facilitating coordinated actions". In the context of this paper, we refer to social capital as the value that these networks, norms of reciprocity and trust have for community members.
} 
were followed by in-depth research at six focus sites involving a combination of methods, including 165 semi-structured household interviews.

Lilongwe District had 449 VFAs. There are three types of VFA: natural (standing, indigenous forest), planted (usually exotics) and mixed (both standing forest and newly planted). Natural forests (of which there were 134) were chosen for the study as opposed to planted or mixed forests as the Forest Policy put emphasis on promoting the regeneration of natural forests (GoM, 1996). A selection of these natural VFAs (97) was then split by size (table 1) and 33 were chosen to provide baseline data regarding the management and use of VFAs. A transect walk was carried out in each of the villages to produce social and resource maps and to locate and observe the VFA. As well as providing important baseline data, the 33 VFAs were used to select six focus sites for in depth study. Selection was based on their size, origin, period of establishment, governance system, benefits, level of conflicts, involvement of other stakeholders and socio-economic characteristics in order to give as wide a representation as possible. These sites enabled detailed investigation to explore the intricacies of local institutions, relationships and to understand the effects of the policy, through semi-structured household interviews, key informant interviews, focus group discussions and observation. In total 165 semi-structured household interviews were carried out across the six focus sites; in addition key informant interviews were undertaken with stakeholders involved in the development and implementation of the forest policy (Director of Forestry, District Forestry Officers and staff of local NGOs) as well as village heads, Village Natural Resource Management Committees (VNRMCs) and Forestry Assistants at village level.

\section{Table 1 about here}

Alongside the semi-structured household interviews, 24 focus group discussions (split by men, women and youths as separate users of forest resources) were undertaken across the six focus sites. Focus group discussions were important for gathering information relating to benefit sharing arrangements, the effectiveness of VNRMCs in forest management and how they use the authority and powers in decision making to govern resources on behalf of their constituents. In addition to the village level focus groups, a discussion was conducted with Forest Department headquarters staff using a discussion paper that summarised insights from the field work.

Forest Resource Assessments were carried out at each of the six focus sites, in order to assess the condition of the forest. The assessment provided information on species stocking density, species 
composition and harvested tree species. This information was used to establish the availability of forest resources to the village, information that is necessary to understand the character of the natural resource base that local institutions have to manage. Qualitative data were analysed using content analysis to aid identification of themes and interpretation of information. Quantitative data from household semi-structured interviews and forest resource assessments were analysed using descriptive statistics.

\section{Results}

The study found that the Forest Policy in Malawi had very significant negative short and long term effects on individuals, communities and village forests. Before considering these in detail it is necessary to outline the context of the policy, and its development and implementation. This was based on document analysis and interviews with key informants involved in the policy both within and outside Malawi.

\subsection{Forest Policy in Malawi}

The Malawian Forest Policy (1996) was an attempt to transfer powers of forest management to local communities through newly created VNRMCs.

\subsubsection{History of forest management in Malawi}

Formal involvement of Malawian village communities in forestry began in 1926, with the launch of the VFA scheme which aimed to provide each village with an area of woodland from which they could obtain a sustainable yield of poles and firewood (Topham and Townsend, 1937; Kalipeni and Zulu, 2002). Since independence (1964), forest management was first decentralised before mismanagement saw its recentralisation in 1984. Despite this, exploitation of forests on customary or common-access lands (which remain de facto open access) continued for livelihood needs of local communities. As the population increased so too did forest degradation. This deterioration prompted the Malawian Government to consider new approaches. The growing consensus, which was pushed more by donors such as UNDP and FAO than from within Malawi (GoM, 1990; FAO, 1992; Banda, 2003), was that local communities should be empowered to manage or have the potential to manage natural resources on a sustainable basis. Under pressure from donors holding funding for proposed forestry projects, a revised national forest policy was implemented in 1996 and the Forestry Act in 1997. The forest policy was drawn up by an international consultant provided by the FAO. It was finalised in consultation with the Ministry of Natural Resources and the Ministry of Justice, without the input of the Forestry Department and its technical staff.

3.1.2 Analysis of the Forestry Act (1997) 
The 1996 Forest Policy marked a major shift in policy from 'protection' forestry to people 'participatory' forestry, promoting CBFM (Kambewa and Utila, 2008). This was to be achieved through the creation of VNRMCs (a form of institutional framework) who would be entrusted with the responsibility of managing customary forests by managing existing or setting up new VFAs, collecting funds from the sale of forest produce and encouraging the usufruct rights of forestry resources by communities and individuals. Alongside the communities, other actors influence VNRM institutions, including the government (through the Forestry Department), NGOs and other civil society organisations. VNRMCs were central to the implementation of the Forest Policy and once elected, were expected to facilitate formulation of and enforce rules for communal governance of VFAs, with assistance from the local Forestry Assistant. However, in practice, few VNRMCs were given legal authority to manage and control forest resources because rules drawn up by the VNRMC had to be approved by the Minister responsible for forestry or had to be under a forest management agreement signed by the Minister. This process of approval was a major obstacle to empowering communities and their representatives to make decisions on forest management.

During the process of policy development there was very limited consultation. This included two workshops for key stakeholders (mainly government officials) and three regional workshops (in 1996) where Traditional Authorities ${ }^{2}$ could give their views on forest resource management. The workshops came late in the process of policy development and after key decisions had already been taken. Therefore views of participants were not reflected in the final policy which was developed without robust consideration of communities, institutions or stakeholders. Traditional systems of forest management were ignored, despite the fact that local communities had for many years been managing standing VFAs (and graveyards) with effective customary regulations (as highlighted by Morris (1995) and Kowero et al. (2003).

Forest Assistants in the Forest Department were given responsibility for communication and implementation of the policy in communities. They received limited training and although the Forest Policy and Forestry Act were translated into three vernacular languages (Chewa, Yao and Tumbuka), a lack of resources (e.g. transport) meant that these documents were not used. Communication methods used by the government were therefore ineffective and communities were unaware of the goal of the policy, namely their participation in forest management. The Community Partnership for Sustainable Resource Management commissioned a number of surveys to identify problems with

\footnotetext{
${ }^{2}$ Traditional authorities in Malawi play a role in the administration of local government and are seen as custodians of local culture (UNFPA, n.d.). They play a significant role in matters of social cohesion and conflict resolution (Ellis et al., 2003).
} 
forest policy implementation and found that there was a huge discrepancy in policy knowledge between the forest extension staff and the local community. Garforth (2005) reported similar findings with respect to the fertiliser subsidy programme.

\subsection{Impacts of the Forest Policy - doing more harm than good?}

The impacts of the Forest Policy were varied in type and scale. Whilst some were minor, others had further reaching consequences that had greater and potentially long-lasting impact upon institutions and communities. The main impacts upon the 33 VFAs that were selected for the baseline survey are summarised in table 2 .

\section{Table 2 about here}

Table 2 shows that almost a fifth of VFAs (18\%) had been cleared. Over a quarter (27\%) of VFAs had a level of conflict ${ }^{3}$ that was considered 'high' whilst another quarter (24\%) displayed a 'medium' level conflict and only one VFA had no conflict. All bar one of the VFAs experiencing high levels of conflict were either governed by the village headman rather than a VNRMC or a combination of both the village headman and the VNRMC. Governance of the VFAs is not as envisaged in the policy. Only one of the VFAs (Kapazanje) was solely controlled by the VNRMC.

The conflicts that are summarised in table 2 reflect the breakdown of traditional institutions ${ }^{4}$, weak creation of new institutions (VNRMCs), fractured social relations and erosion of social capital. One unintended consequence was the strengthening of self-serving institutions and the reinforcement of power balances in favour of elites. As discussed earlier, the consultation process during policy formulation was unsuccessful in enabling the voices of local authorities, communities and NGOs to be heard. This led to the implementation of the policy being driven with little knowledge of the institutions already in place in local communities. The approach tried to impose new community institutions in areas where traditional systems were in place. Inevitably, this created confusion as communities were expected to introduce a new set of structures that either mirrored or attempted to usurp existing institutions; confusion that was exacerbated by the poor communication of the policy. Significantly, this confusion left opportunities for malpractice by powerful community

\footnotetext{
${ }^{3}$ The level of conflict was a subjective classification, made by the authors, of the seriousness of conflict in the area of the VFA, i.e. Low = fully functioning VNRMC and standing VFA; High = VFA cleared for cultivation or sale and major breakdown in community relations.

${ }^{4}$ Formal and informal institutions which include rules governing access to resources, traditional leadership structures, social and cultural norms, authority and power to make decisions and measures to hold elites accountable.
} 
members as well as by outsiders (i.e. Forestry Assistants and Traditional Authorities). The following sections explore in more detail the nature and extent of the effects outlined above.

\subsubsection{Elite Capture}

Elite capture was evident to varying degrees, across a large number of the VFAs visited (see box 1). Chinsinga (2005) reported similar findings when analysing distribution of fertiliser subsidies in Malawi. Some of these examples highlight individuals or groups showing disregard for existing institutions regarding resource management (e.g. in Bisai and Gomani) whilst others highlight the use of new institutional structures for their own gain (e.g. in Gumbi and Mtembe). All of these incidences impact upon local institutions and their relationships with community members. In most cases villagers have had to accept elite capture and have no means of holding either influential members of their communities or outsiders to account ${ }^{5}$.

\section{Box 1 about here}

Elite capture was a problem both within communities (local-local elite capture) and with external actors (external-local elite capture). In Chabuka village there was an example of local-local capture to the detriment of the community. The community had set up a programme where sales of wood from the VFA helped pay primary school teachers (years one to three), thereby benefiting the whole village. However, the chairperson of the VNRMC started to exploit the VFA for his own benefit, firstly demanding money from the treasurer (who was married into the village and so easier to manipulate) and later cutting down half of the VFA and selling the wood to charcoal vendors. The villagers no longer had cash to pay the teachers' salaries and the school was closed, causing longterm damage to the legitimacy of local natural resource management institutions in the community and the loss of a valuable service. In Gumbi village, the chairperson of the VNRMC sold poles from the VFA on more than one occasion and kept the profits for himself and his father, who was the group village headman. In Sinyala village, the community were unable to benefit from the sale of VFA wood. Firstly, money from wood cut whilst making a firebreak was split between the village headman and the chair of the VNRMC, rather than distributed, and secondly, the VNRMC were slow in making a decision about the sale of coppiced wood and most of it was stolen.

Control and ownership of VFAs was being contested in a variety of situations, including their conversion to farmland, settlement, graveyards and other cultural uses. In Chisomba village, the

\footnotetext{
${ }^{5}$ This study focussed on the Lilongwe district and that the strength of self-serving institutions and elite capture should not be considered to be necessarily representative of other areas of Malawi.
} 
headman was being challenged by his nephew over the rights to the VFA as the nephew's mother was the previous village head and he wanted to cultivate part of the VFA. Such struggles over ownership impact on the wider communities' ability to utilise resources from their VFAs. In Mkombe village, two brothers, one of whom was village head, contested ownership and control of the VFA. Due to this feud, the rights of access became dependent upon which brother a person was most closely connected to. Those closest to the group village headman were not allowed to collect any product from the VFA while those closest to the chairman could, with permission, collect both wood and non-wood products.

There were also examples of external-local elite capture. In Sinyala, there was a complicated situation in which the Forestry Assistant facilitated the setting-up of a community based organisation and then promptly appointed himself as director with a board of trustees mainly made up of Forestry Department staff. The Forestry Assistant then blocked the direct flow of resources from interested stakeholders to VNRMCs/VFAs in the area. In this case, government staff have become part of a community organisation, running the affairs of the community instead of facilitating the activities, and as a result damaging social capital. Important decisions are made by Forestry Department staff and assistance is routed through the community based organisation. The various VNRMCs in the area then only have access to benefits (farm inputs, tools, study tours, training and income generating activity [IGA] inputs) by joining the community based organisation for a membership fee. Shackleton et al. (2002) reported a similar problem in India, where elite men and forest department officials took over forest protection committees run by women and limited their access to resources. In Chalera village, a member of staff from an NGO borrowed seedlings for an agricultural show. The community raised the seedlings and were told they would be returned and remuneration given for their use; neither of these things happened.

Resources that were promised to villages did not always materialise. In Chindima village the Forestry Assistant told the village head to mobilise the community to set up a tree nursery for which the Forestry Department would provide polythene tubes, seeds and tools. However, the inputs were not forthcoming and an NGO provided them instead. The Forestry Assistant then took the tools to create his own nursery and did not return them. The same Forestry Assistant was accused of embezzling money that was meant for the villagers for raising and planting their seedlings. These actions erode the trust of the local community, making it less likely that they will engage in future initiatives of benefit to their livelihoods. 
The felling of trees in VFAs and the seizure of resources outlined here highlights the lack of transparency and accountability of the VNRMC and the traditional leadership system, and explains the erosion of trust in these institutions that are crucial for local communities. It is clear that the introduction of the Forest Policy, its flimsy, imposed structures and the confusion caused by its communication has encouraged the problem of elite capture and has contributed to the breakdown of social capital, impacting negatively on individual and community access to resources. This erosion of social capital as a consequence of elite capture of resources is a problem that is often cited in research on participatory projects (Mansuri and Rao, 2004; Dasgupta and Beard, 2007; Fritzen, 2007).

\subsubsection{Expectations and negative consequences of incentives}

In encouraging the development of VFAs, the Forestry Department (in liaison with a number of mainly international and NGO funded projects supporting forest management) offered communities the potential of IGAs as well as cash payments for forest management, tools, boreholes and other benefits (e.g. field visits). The incentives encouraged communities to demarcate VFAs. For example, neighbouring villages to Gumbi established their VFAs on the basis of incentive measures. A village headman from Mthunzi said "we established our own VFA because we were envious of our colleagues from Gumbi. They have an irrigation project, a borehole and [had] other benefits because of the forest and in the future we want to benefit from such incentives". To those who brought in the incentives, the positive response of villagers was viewed as an indication of willingness to participate in VFA management. However, the idea of using incentive measures with no clear link to forests in order to encourage participation in VFA management had negative consequences.

Firstly, whilst incentives encouraged local interest and desire to be involved in VFA management, they raised expectations and acted as an additional focus and opportunity for elite capture. For example, in Msumati village, the VNRMC chose to use funds and support to start a broiler chicken business due to their close proximity to Nkhoma Mission, which was considered to be a potential market for the chickens. Issues related to accessing training in business management (see box 2) provided opportunities for elite capture and led to the management of the VFA being dominated by the village headman and his family, including his sister cultivating part of the VFA land, which brought allegations of fraud and halted benefits to the wider community. In this case the introduction of incentives was detrimental to existing established institutions regarding access to forest resources, and the weak, imposed VNRMC structures proved to be fragile in the face of conflict, and negatively affected the entire community. An additional factor was that other projects that had previously worked in communities had used incentives, including paying cash, for VFA 
management (e.g. European Union Village Investment Forestry and European Union Public Works Programme). They therefore left a 'legacy' regarding expectations that contributed to some of the 'manoeuvring' and 'infighting' that took place in communities when the forest policy was implemented. This was not considered in the development or implementation of the Forest Policy.

\section{Box 2 about here}

Secondly, use of incentives to encourage individuals and communities to implement policy and activities devised and brought in from 'outside' can be interpreted by local people as 'payment' for doing what a project or government wants. It is clear that aspects of VFA management were implemented by some elites in communities in order to access incentives rather than achieve the benefits for which they were intended, resulting at best in limited 'ownership' and no motivation to continue with the management processes once the incentives cease. Kiptot et al. (2007), in their longitudinal study of adoption of agroforestry innovations in an area of Kenya, refer to 'pseudoadopters', who temporarily adopted and readopted practices, in order to access inputs and credit provided by a series of projects.

\subsubsection{Conflict between traditional and 'imposed' institutions}

The Forest Policy structures, engineered by the Forestry Department ignored locally generated resource use rules which reflect local customs, sanctions and conflict resolution mechanisms. A key finding from this study is that provisions in the policy and law suggest that there was no adequate analysis and examination of traditional or customary rules and norms for forest management, which were incorporated into law. Both the Forest Policy and Act ignored the Traditional Authority's role in forest management and VNRMC institutions were superimposed onto existing traditional structures of forest management. However, Traditional Authorities have devised ways to regain their authority and remain legitimate in the eyes of the wider community. This has created dual authority at the local level and power imbalances because of hierarchical ambiguities.

The lack of precise articulation of institutional arrangements and mandates for forest management in the law in relation to VNRMCs and Traditional Authorities has left laws open to interpretation; for example, by traditional leaders shaping VNRMC membership and taking control of forest management. In some cases the Forestry Assistants and other Forestry Department staff have acted as an elitist group that have taken benefits away from local communities (section 3.2.1). Such tactics have precluded local institutions from making decisions on resource use, undermining their authority. The dilemma lies in the fact that the Forestry Assistants serve as a link between the state 
(Forestry Department) and local communities managing forests and are central to implementation of official forest policy. Front line personnel under devolution arrangements may resist change because devolution threatens their roles, and because new bodies may be given the power to take over decisions that they had been used to making (Ribot and Oyono, 2005; Blaikie, 2006).

An example where the confusion of dual authority can be highlighted is in the punishment of those who break rules governing forest management. Traditionally, a penalty is charged in kind and not in cash, as cash is extremely difficult to come by. Penalties range from payment of live animals, work, returning the collected produce, confiscation of tools and, in severe cases, referral to the police. The villagers chose fines that are practical and that can be achieved, whilst Forestry Department staff wanted villages to follow Forestry Act rules and penalties. The village headman in Sinyala questioned whether following the Forestry Department's rules brought into question who owned the VFAs "I thought that the government said that this forest is ours, how come they tell us how to make rules for our forest?". Again, this is an example of the implementation of the Forest Policy eroding social norms.

\subsubsection{Ownership and decision making}

Although the Forestry Act provides ownership on the basis of a Forest Management Agreement, at local level, village communities contest ownership based on customary law i.e. the understanding of allocation of customary land by village headship. Village heads were perceived by communities to have authority over VFAs, and in each of the villages at least as many households believed that village heads' controlled VFAs as VNRMCs (table 3 ).

\section{Table 3 about here}

A VNRMC member of Gumbi village commented that "we cannot do away with village heads; these are our eyes and that's why when you [forestry officials] come into a village you do not ask for a chairperson of the VNRMC but the village headman, even when you know that VNRMC exist". Despite being given authority by the Forestry Act over VFA resources, VNRMC members also recognise the traditional leadership as being in charge of resources in the village.

Villagers across the focus sites considered VNRMCs to have the power to be able to make decisions, to ensure compliance and to adjudicate but the majority did not consider them to have the power to create rules. Villagers considered village headmen as the individuals with the most power over 
decisions on forestry; this was only not the case in Chimdima where $93 \%$ of villagers considered the VNRMC to hold influence over decision making.

\subsubsection{Accountability}

Lack of accountability and corruption was a recurrent concern in villagers' narratives. A number of accountability measures were reported to exist in the villages. Focus group discussions highlighted the fact that VNRMCs and Forestry Assistants were generally not accountable to the wider community and that VNRMCs were only upwardly accountable to Forestry Assistants, due to alliances or relationships that were developed in the course of governing VFAs. In terms of village heads, some were held accountable and others were not.

In Gumbi village, $82 \%$ of households ( $n=66$ ) reported that the VNRMC does not report to the wider village nor call for meetings. Forest related issues are reported when the group village headman calls meetings and are discussed as miscellaneous items on the broader meeting agenda or during funerals. Villagers in Gumbi did not demand accountability in the form of reporting because they fear the chairperson of the committee, who is believed to be a witch. Dismissal and renewal of representatives as a mechanism of accountability was not widely practiced and in the majority of villages there had been no renewal of representatives since the initial elections/nominations. Furthermore, terms of office for VNRMC members, including term lengths or limits, did not exist, and in communities where they had been specified, were ignored by those in charge.

The VNRMCs were reported not to be transparent in decision making for forest management in five of the six villages; the exception was Chimdima where all households said that decisions were transparent. Villagers also claimed that Forestry Assistants did not operate in a transparent manner and influenced VNRMCs to make decisions that benefited them rather than the local community. Therefore VNRMCs did not operate accountably to the wider community that they represented. Almost three quarters of villagers (71\%) said that there was no transparency over forest governance.

\subsubsection{Transfer of power}

In theory, VNRMCs are supposed to be democratically elected community level committees that represent local communities in VFA management. In reality, formation of VNRMCs was externally driven and overseen by Forestry Assistants who were given little guidance on how to facilitate the process. Rather than being democratically elected, the composition of VNRMCs was often manipulated by Forestry Department staff and community elites who nominated committee members (e.g. Gumbi and Msumati). Where elections were held, the parameters were decided by Forestry Department staff and elections could not be considered to have given voice to local people 
in deciding their representatives. An example of this form of manipulation by local elites or traditional leaders was that in each of the focus site villages, the position of treasurer was deliberately given to a woman or a man that was married into the village. Those who marry into a village have little standing or influence; the treasurer from Msumati village stated that "they deliberately nominated me as a treasurer so that they can easily request money from me because I am in a matrilocal residence. I do not belong here. Anytime they can chase me away because my wife died".

The mechanisms to transfer decision making powers as stated in the policy are prohibitive in that they require elaborate forest management plans to be developed. Furthermore the plans have to be developed with the Forestry Assistants' expertise, which varies from place to place. As stated earlier, the forest management plans go through a long approval process involving the Minister responsible for forestry to become a Forest Management Agreement, which can then be withdrawn by the Forest Department if management of the VFA is poor. The difficulties in transferring power both within a VNRMC through democratic elections, and to a VNRMC through a forest management plan, weakens their standing as institutions in the eyes of the community (e.g. Msumati, where committee positions were given to relatives of traditional authorities, before squabbling over incentives led to the breakdown of VNRMC structures). If the policy had been truly 'communitydriven', the government would have had to relinquish more of their power instead of merely introducing more coercive means of monitoring forests. VFAs appear to be being managed to promote the strategies of government and other outsiders rather than for community use and, as such, they resemble government forest reserves with little management (similar issues are reported by Shackleton et al. (2002) in Botswana, Namibia, India and China). The result of this is that communities remain without the power to make any effective forest management decisions.

\section{Discussion and conclusion}

The aims of this paper are to explore the effects of limited involvement by local people and institutions in policy development and implementation, identifying implications for future research and policy development.

It is argued that limited consideration of existing local institutions in CBNRM policy can create more harm than good and far greater emphasis needs to be given to address this within policy development. Interventions that do not succeed seldom have 'neutral' consequences, and can have a range of unplanned negative effects, which influence the abilities of communities and in particular 
the poor within them, to access resources, cope with and adapt to challenges, and benefit from future opportunities. Policy that seeks to change institutions needs to be built on clear understanding of the often complex nature of existing local institutions and of how they may influence possible outcomes. Only then can appropriate means and facilitating processes be developed and included in policy. CBNRM therefore requires significant investment in both policy development and implementation for it to be successful. Furthermore, weak government buy-in to CBNRM initiatives is likely to translate into a 'business as usual' top-down sectoral approach to natural resource management.

Evidence within this paper clearly shows that the harm resulting from the Forest Policy was both short and long term: VNRMC structures failed, VFAs were cleared of trees, communities were denied resources that belonged to them, conflict was heightened within communities and families, institutions were undermined and social capital was eroded. Immediate damage was done to community members' natural resource base, as they were denied resources that they had previously been able to access, income that was owed to them was taken by people in positions of power, a school was closed and in some cases individuals were criminalised by overzealous forest guards. Self-serving institutions that facilitated elite capture were strengthened whilst long term damage was done to established institutions that controlled natural resource management and more widely to trust and relationships necessary to provide a safety net for vulnerable community members.

The breakdown of trust and relationships undermined social capital. In this way the harm has impacted most upon the poorest members of the community as it is they who rely most upon their traditional institutions for information, guidance, help and support and gain most from developing social capital (Grootaert and Narayan, 2004). Leach et al. (1999, p.240) highlight how important local institutions are for individuals, stating that "rights to access trees for woodfuel may be of little use to generate income unless combined with kin-based claims on labour for wood-cutting and transport, and trading networks for effective marketing". Social capital is based around trust, which has in this case been undermined, and commonly shared 'social norms' which "influence people's preferences and constraints, lower transaction costs, facilitate the exchange of information, and enable societies to overcome social dilemmas" (van Rijn et al., 2012, pp. 113). Mansuri and Rao (2004) point out that the better off may have access to better internal and external networks that they are able to use to reproduce unequal systems of domination. The poor rarely have access to these networks and that is why these effects are so damaging and long term. 
The lack of consultation and the poor communication of the policy led to a vacuum of information into which local elites and outsiders could step in order to take advantage of areas of the policy where they saw potential for personal gain (as Zulu [2008] found in his study in southern Malawi). Elite capture is often considered a problem with community based development (Platteau and Abraham, 2002; Platteau, 2004; Chinsinga, 2005; Fritzen, 2007; Zulu, 2008) and though local institutions can help to build and improve social capital, the existing social and power structures that they may enforce can constrain its formation (Grootaert and Narayan, 2004), as Pelling et al. (2008, p. 869) state "institutions give shape to, whilst being reproduced by, repeated rounds of customary behaviour". As Mansuri and Rao (2004, pp. 9) state, "social capital can be used to facilitate collective action for the common good or to perpetuate symbolic or actual violence against others". These power structures and differentials are, to some extent, inevitable, meaning that it may be more effective to focus on developing something more akin to 'elite control'. Fritzen (2007, pp. 1372) suggests that more attention should be paid by "analysts and project planners to learning what mechanisms may raise the likelihood that elites will play a constructive role in community development" rather than focussing on avoiding power differentials altogether.

As Chinsinga (2005) found, when discussing targeting of fertiliser subsidies, involving communities in policy decisions at the design stage is important; giving policy makers access to local knowledge and fully informing communities of the policy goals and incentives, whilst allowing communities to factor in their own, "location-specific notions of need, equity and entitlement" (ibid, pp. 298). In some cases, elite capture may be well intentioned and benevolent (Dasgupta and Beard, 2007) whereas others may be "greedy individuals who show all the less restraint in enriching themselves at the expense of their community as they are actually legitimated by outside actors" (Platteau and Abraham, 2002, pp. 122). Problems with elite capture make it even more important to interact with local institutions and stakeholders and to ensure good communication; as when local people are aware of their rights and are knowledgeable in terms of policies that guide committees that manage natural resources then they are able to challenge elitist and self-serving behaviour (Shackleton et al., 2002; Zulu, 2008). Customary institutional structures which are often flexible, socially negotiable and hence, more practical, should not be viewed and treated as being inferior to statutory institutional structures but should be worked with in order to build systems of accountability.

One of the potential major negative impacts in the long term is that those community members who lost out due to the poorly implemented policy are unlikely to trust a new initiative (e.g. Grant, 2001) and those who gained at others expense are likely to look for further possibilities to gain (e.g. 
Platteau [2004] and his discussion on 'development brokers'), giving fresh initiatives little chance of success from the beginning. 'Destructive' and rent seeking behaviours can therefore become new or more reinforced 'norms' in communities as a result of poor policy and implementation. There may be a cumulative effect over time, as probably occurred here, where successive outside interventions did not address issues of elite capture, and in addition offered IGAs and incentives that were not directly related to project goals. Perhaps more seriously the breakdown of social capital, institutions and trust leaves a community with less capacity to solve problems themselves as they arise and to take initiative on future issues that may improve livelihoods.

Whilst there are underlying causes for the harm that occurred during implementation of the policy, local institutions and some individuals were guilty of positioning themselves at the expense of others and exploiting the benefits that came with the policy. It is a fault with policy development that these were not taken into account and considered in policy development and implementation. In this way the policy helped to exacerbate these underlying causes that developed into 'harm'.

The poorly considered IGAs left a disconnect between the policy goals, sustainable forestry management, and the tangible benefits that community members could see from the project. Introducing IGAs gave the appearance that communities were being enticed by unrelated incentives in order to achieve externally driven policy goals, rather than fostering a sense of mutual achievement through benefits linked to forestry. The lack of any effective consultation during the development of the policy meant that local institutions and rules that managed forest resources were not taken into account and there was little opportunity for local communities and their representatives to make decisions on forest management; this did not allow for a sense of ownership over the policy. Poor communication of the policy led to a vacuum of information into which local-local and external-local elites could step in order to take advantage of areas of the policy where they saw potential for personal gain (as Zulu [2008] found in his study in southern Malawi and Kellert et al. [2000] found in Kenya and Nepal). The conflict between traditional and imposed institutions added confusion and allowed traditional leaders to shape VNRMC membership and take control of forest resources. The lack of accountability and difficulties associated with transferral of power meant that those elites, local and external, that were benefitting from manipulation of the policy had no recompense and communities were left unable to change the balance of power.

Local institutions are considered to have a role as mediators for external interventions (Agrawal and Yadama, 1997; Leach et al. 1999; Agrawal, 2010; Saunders, 2010). However, institutions will not 
necessarily fulfil their role as mediators and that they may well take advantage of policy in order to further their own gains.

International thinking on natural resource management promotes the involvement of local people and institutions in the implementation and delivery of natural resource use in order to build capacity, limit costs and achieve scale and sustainability. Whilst this approach can be argued to be appropriate, as evidenced in this paper, no matter how strong the policy may be, its goals will not be achieved and significant long term damage may occur if the design and implementation at the local level is flawed. This may be particularly likely where natural resource management initiatives are externally driven and do not generate necessary national government ownership. Any legal mechanism, policy or programme will encounter a range of local conditions and unique dilemmas in its implementation. Approaches are required in policy development and implementation that facilitate enabling local institutions to be fully engaged in the process of making the policy truly community driven, whilst limiting the impact of self-serving institutions; bringing clarification and shared understanding of the goals of all stakeholders; and incorporating flexibility at the local level with respect to institutions and mechanisms.

\section{References}

Agrawal, A. 2010. Local Institutions and Adaption to Climate Change. In Mearns, R. and Norton, A. (eds.), The Social Dimensions of Climate Change: Equity and Vulnerability in a Warming World. The World Bank, Washington, pp. 173-198.

Agrawal, A., Perrin, N. 2008. Climate Adaptation, Local Institutions, and Rural Livelihoods. IFRI Working Paper W08I-6. University of Michigan, 17pp.

Agrawal, A., Yadama, G.N. 1997. How do Local Institutions Mediate Market and Population Pressures on Resources? Forest Panchayats in Kumaon, India. Development and Change, 28, 435-465.

Banda, G.Z. 2003. Harmonisation of Environment and Natural Resources Management policies in Malawi. Environmental Affairs Department, Lilongwe.

Blaikie, P. 2006. Is Small Really Beautiful? Community-based Natural Resource Management in Malawi and Botswana. World Development, 34 (11), 1942-1957.

Chinsinga, B. 2005. The Clash of Voices: Community-based targeting of safety-net Interventions in Malawi. Social Policy and Administration, 39 (3), 284-301.

Dasgupta, A., Beard, V.A. 2007. Community Driven Development, Collective Action and Elite Capture in Indonesia. Development and Change, 38 (2), 229-249.

Ellis, F., Kutengule, M., Nyasulu, A. 2003. Livelihoods and Rural Poverty Reduction in Malawi. World Development, 31 (9), 1495-1510. 
Food and Agriculture Organisation of the United Nations. 1992. Options for Institutional Arrangements for the Tropical Forests Action Programme: Second Meeting of the adhoc group on the Tropical Forests Action Programme. Rome.

Fritzen, S.A. 2007. Can the Design of Community-Driven Development Reduce the Risk of Elite Capture? Evidence from Indonesia. World Development, 35 (8), 1359-1375.

Garforth, C. 2005. The Challenges of Agricultural Extension. In: Levy, S. (ed.), Starter Packs: a Strategy to Fight Hunger in Developing Countries? CABI Publishing, Wallingford, UK, pp. 175-191.

Government of Malawi. 1990. Application for FAO Assistance to Implement the Tropical Forestry Action Plan in Malawi. Ministry of Forestry and Natural Resources, Lilongwe.

Government of Malawi. 1996. The National Forest Policy. Ministry of Natural Resources and Environmental Affairs, Lilongwe.

Grant, E. 2001. Social Capital and Community Strategies: Neighbourhood Development in Guatemala City. Development and Change, 32, 975-997.

Grootaert, C., Narayan, D. 2004. Local Institutions, Poverty and Household Welfare in Bolivia. World Development, 32 (7), 1179-1198.

Hobley, M. 2005. Building State-People Relationships in Forestry. ODI Forest Policy and Environment Programme, Grey Literature.

Kalipeni, E., Zulu, L. 2002. From top-down to bottom-up: the difficult case of the Blantyre City Fuelwood Project. Journal of Southern African Studies, 28 (1), 117-136.

Kambewa, P., Utila, H. 2008. Malawi's green gold: Challenges and opportunities for small and medium forest enterprises in reducing poverty. IIED small and medium forestry enterprise series no. 24. International Institute for Environment and Development, London.

Kellert, S.R., Metha, J.N., Ebbin, S.A., Lichtenfeld, L.L. 2000. Community Natural Resource Management: Promise, Rhetoric, and Reality. Society and Natural Resources, 13, 705-715.

Kiptot, E., Hebinck, P., Franzel, S., Richards, P. 2007. Adopters, testers or pseudo-adopters? Dynamics of the use of improved tree fallows by farmers in western Kenya. Agricultural Systems, 94, 509-519.

Kowero, G., Campbell, B.M., Sumaila, U.R. 2003. Policies and Governance Structures in Woodlands of Southern Africa. Centre for International Forestry Research, Bogor.

Leach, M., Mearns, R., Scoones, I. 1999. Environmental Entitlements: Dynamics and Institutions in Community-Based Natural Resource Management. World Development, 27 (2), 22-247.

Mansuri, G., Rao, V. 2004. Community-based and -Driven Development: A Critical Review. World Bank Research Observer, 19 (1), 1-39.

Morris, B. 1995. Woodland and Village: Reflections on the 'Animal Estate' in Rural Malawi. The Journal of the Royal Anthropological Institute, 1 (2), 301-315. 
Pelling, M., High, C., Dearing, J., Smith, D. 2008. Shadow spaces for social learning: a relational understanding of adaptive capacity to climate change within organisations. Environment and Planning A, 40, 867-884.

Platteau, J-P. 2004. Monitoring Elite Capture in Community-Driven Development. Development and Change, 35 (2), 223-246.

Platteau, J-P., Abraham, A. 2002. Participatory Development in the Presence of Endogenous Community Imperfections. Journal of Development Studies, 39 (2), 104-136.

Putnam, R. D. 1993. Making Democracy Work: Civic Traditions in Modern Italy. Princeton University Press, Princeton.

Ribot, J.C. 2002. Democratic Decentralisation of Natural Resources: Institutionalising Popular Participation. World Resources Institute, Washington DC.

Ribot, J.C., Oyono, P.R. 2005. The Politics of Decentralisation. In: Wisner, B., Toulmin, C., Chitiga (Eds.), Towards a New Map of Africa. Earthscan, London, pp. 205-228.

Saunders, F. 2010. A Political Ecology Inspired Critique of Common Pool Resource Theory and Practice. In Friman, E. and Fernandez, G.L.G. (eds.) Politicized Nature: Global Exchange, Resources and Power. CEFO Publication Series, No. 2, Uppsala University, pp. 23-48.

Shackleton, S., Campbell, B., Wollenberg, E., Edmunds, D. 2002. Devolution and Community Based Natural Resource Management: Creating Space for Local People to Participate and Benefit. ODI Programme for Land and Agrarian Studies, London.

Tacconi, L. Siagian, Y., Syam, R. 2006. On the theory of decentralisation, forests and livelihoods. Environmental Management and Development Occasional Papers, 9. Australian National University, Canberra.

Topham, P., Townsend, R.G.R. 1937. Forestry and Soil Conservation in Malawi. University of Oxford: Imperial Forestry Institute, Oxford.

Toulmin, C. 2008. Securing land and property rights in sub-Saharan Africa: The role of local institutions. Land Use Policy, 26 (1), 10-19.

UNFPA. No date. Malawi: Mobilizing Religious and Traditional Leaders in the Fight against HIV/AIDS. http://www.unfpa.org/culture/case studies/malawi study.htm [accessed 26-03-2013].

van Rijn, F., Bulte, E., Adekunle, A. 2012. Social capital and agricultural innovation in Sub-Saharan Africa. Agricultural Systems, 108, 112-122.

Zulu, L.C. 2008. Community forest management in southern Malawi: Solution or part of the problem? Society and Natural Resources, 21 (8), 687-703.

Zulu, L.C. 2009. Politics of scale and community-based forest management in southern Malawi. Geoforum, 40, 686-699. 